Article

\title{
An Essential Tool for Natural Heritage Management: The Geomorphological Map of Valderejo Natural Park
}

\author{
María José González-Amuchastegui ${ }^{1, *}$ and Enrique Serrano ${ }^{2}$ \\ 1 Department of Geography, Prehistory and Archeology, University of the Basque Country, \\ Vitoria-Gasteiz 01004, Spain \\ 2 Department of Geography, University of Valladolid, Valladolid 47011, Spain; serranoe@fyl.uva.es \\ * Correspondence: mj.gonzaleza@ehu.eus; Tel.: +34-945-014-319
}

Received: 31 May 2018; Accepted: 3 July 2018; Published: 8 July 2018

\begin{abstract}
This study supports the usefulness of geomorphological mapping as a tool for gaining an understanding of the landscape and assessing natural heritage. Mapping provides an essentially scientific document with great potential for the diffusion of geomorphological knowledge in that it provides a guide to the user of natural protected areas as well as serving as a tool for its management regarding geotourist itineraries, geodiversity, and geomorphosites. The example of the Valderejo Natural Park is presented, which is located in Álava (Spain) and whose geomorphology has been mapped following a methodology based on fieldwork, desktop work, and the use of Geographic Information Systems. The map's applications are presented in the areas of tourism, geotourist maps, and for the assessment of natural heritage, geodiversity, and geomorphosites.
\end{abstract}

Keywords: Geomorphological mapping; Geoheritage; natural protected areas; Valderejo

\section{Introduction}

Relief is one of the main elements in the configuration of natural protected areas, and therefore of natural heritage since it determines the distribution of the remaining environmental and territorial factors: climate, vegetation, and land uses. Geomorphological structure is not the only basis of territorial organization. It also often underlies the attraction of these spaces and the reasons behind their declaration as protected areas. Additionally, it is the abiotic elements as well as the infrastructure of the landscape, often its most significant aspect, that lead to the use of the term "geomorphological landscapes" [1].

Geomorphological mapping is an essential tool for acquiring territorial knowledge since it provides a scientific document with great divulgatory and applied potential. Through the convenient adaptation of information, the geomorphological map is a document that brings the user of natural protected areas closer to the knowledge of the territorial articulation of landscapes with strong geomorphological protagonism. Its divulgative nature is enhanced as it allows the design of geotourist itineraries or its use in territorial management, from the elaboration and analysis of geodiversity to the definition and management proposals for geomorphosites. To sum up, geomorphological mapping is an essential tool for establishing a diagnosis of the value of the territorial and patrimonial resources of natural protected areas from the geomorphological point of view, at a time when awareness of geomorphological heritage and the need to develop management proposals linked to abiotic elements of the landscape are growing [2,3]; this approach is in accordance with the 'European Manifesto for the Earth's Heritage and Geodiversity" (2004) carried out by the International Geographical Union (IGU), the European Geoparks Network (EGN), European Society for Soil Conservation (ESSC), and the 
International Union of Geological Sciences (IUGS). It is one of the proposals developed by the Working Group on Geomorphosites of the International Association of Geomorphologists (IAG).

\section{Materials and Methods}

A classical methodological approach was followed in the process of drawing up the geomorphological map of Valderejo based on two elementary blocks: fieldwork and desktop work. The fieldwork was based on the detailed survey of the Valderejo Natural Park following different itineraries, the inventory of landforms and processes, detailed mapping of landforms and data collection (photographs, geographical coordinates ... ). Also, the desktop work consisted mainly of the digital processing of mapping data using basic support tools: the National Topographical Map of Spain, scale 1:25000 (Sheet No 110C4) and aerial photography of the area studied. The present study has its own digital base drawn up from the topographical base of the National Geographic Institute and the mapping base of the Valderejo Natural Park (Map-Guide).

Furthermore, an analysis was made of the bibliographic information (geographic, geomorphological, historical, geological, and urbanistic). The cartographic system of the Spanish Geomorphology Society [4] was used, which combines the French (CNRS-70) and Dutch (ITC system) cartographic systems and adapts perfectly to the cartography of flat areas, fluvial systems, and applied proposals [5].

The generation of the geomorphological map involves the use of maps and a DEM, satellite images and photogrammetric flights (1945-46, 1945-1986, and 2014). The map was drawn up using ArcGIS, transforming all the projection layers to WGS 84 and a 1:25000 scale. The different layers (topography, shading, slopes, contours) were treated using the vectorial drawing program "Corel Draw", and geo-referencing was performed in ETRS 89.

To represent the most outstanding geomorphological aspects of the cartographic system of the Valderejo Natural Park, the French system (R.C.P. 77) and the Institut de Géographie de la Universite de Lausanne (IGUL) were used with suitable graphical adaptations to its characteristics. This methodology has been applied in other Spanish protected areas, such as the Ebro-Rudrón Natural Park or Picos de Europa National Park [6,7]. Genetic and morphological classifications of the relief forms were performed both in the distribution and spatial relationships among them.

A legend based on symbols and colors was used to represent the relief forms according to the morphogenetic system they belong to: structural, karstic, fluvial, and slope. Topographic information makes it easier to read and understand the map, and this is the reason why the main altimetric levels, villages, roads, and the key/legend were included as well as the most representative place names, in addition to the contours. A legend of 29 symbols was also made, classified by topography, anthropogenic, structural, karstic, and fluvial forms and deposits, as well as slope forms. A summary of the geology describing the structural forms (IGME, Sheet 110) was included, which is essential to understanding the relief of Valderejo.

\section{Regional Setting. Valderejo, a Natural Park with a Strong Geomorphological Presence}

The Valderejo Natural Park lies at the western edge of Álava, Spain (Figure 1). Valderejo has an area of $3418.5 \mathrm{Ha}$ and lies at a mean altitude of approximately $1000 \mathrm{~m}(977 \mathrm{~m})$. It was declared Natural Park in 1992.

Valderejo is in the Mountains of Burgos on the southern watershed of the Cantabrica Mountains. Folded relief forms generated by an ejective tectonic with broad sinclines-the sincline of Villarcayo, the sincline of Valdivielso, Ranera-and narrow anticlines are predominant in this area producing folded relief in which the sinclines form negative concordant relief forms and the anticlines positive relief.

Accordingly, Valderejo forms part of a large anticlinal axis—the anticline of Lahoz-bordered by the Bóveda and Arcena mountain ranges. These form the limbs of a large eroded anticlinal structure, a combe which coincides with the park limits. In fact there is a great coincidence between the surface 
the Natural Park covers and geological structure, which confirms the dominance of geomorphology in defining the Park.

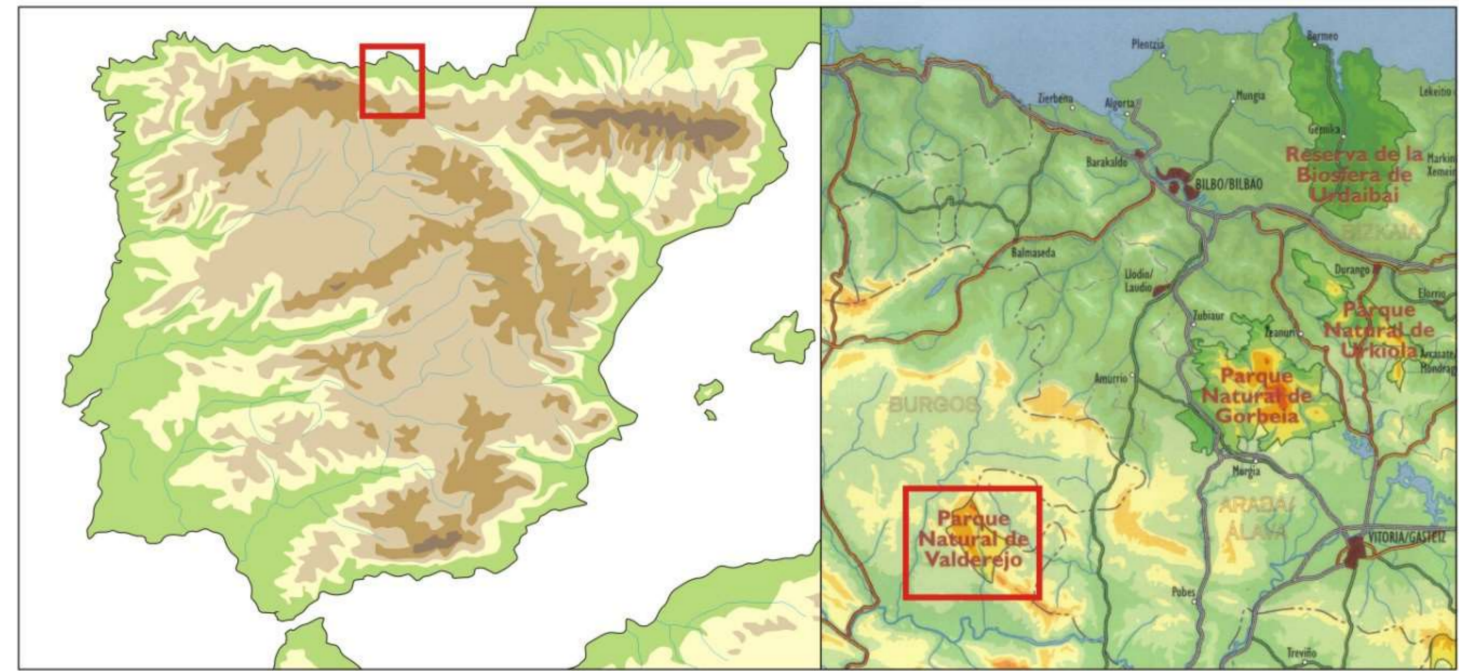

Figure 1. Study area.

Cretacic carbonated materials predominate, in which limestone and dolomites alternate with the limestone levels; the nucleus of the anticline is made up of sands from the Albien stage, which constitute a depressed sector. The limbs present differential dips with a practically subvertical northern limb and a less inclined southern one; its nucleus is faulted by an E-W system of fractures. It has an elliptical morphology as a result of the NW periclinal closure, which gives rise to the combe of Arcena. In itself, this is a geomorphological element that articulates the landscape and the internal organization of the territory, a singular element of high pedagogical and scientific value.

In this structural context, the fluvial network has been the main morphogenetic agent $[6,8]$, with fluvial forms corresponding to a long environmental evolution alternating between phases of accumulation and erosion. The Purón River, a tributary of the Ebro River, runs through the park inciding on the Turonian marls of the anticlinal nucleus to zig-zag across its southern flank such that it adapts to the different types of materials it encounters. The morphology of the valley adapts to the structure, broad stretches of the valley alternating with gorges due to the succession of marls, orthoclinal corridors, and monoclinal limestone bars that define the structure of the southern flank.

The predominance of calcareous materials in the flanks determines the importance and breadth of the karst morphologies (Figure 2). The exokarst landforms develop mainly in the dome of the periclinal closure or from the flanks of the anticline, represented by fields of sinkholes and channels from the areas of Recuenco, Vallegrull, and Arrayuelas. The endokarst presents a more acute development though it has yet to be studied in depth.

Tufa formations constitute the corresponding deposit to an intense karst activity, filling the bottom of the valley of Purón where they reach $25 \mathrm{~m}$ of thickness. Two tufa morphotypes predominate, some autoctonous, and cascade barriers whose genesis is linked to small ruptures in the slope at the bottom of the valley, which trigger the carbonated precipitation (Figure 3). Within this typology the tufa waterfalls stand out, several meters in height and splashing the actual riverbed, though with very reduced functionality, and providing a testimony to ancient dynamics. Upstream from the tufa barriers, the waters of the river have been partially retained leading to a considerable calcarenitic infill in these areas; this infill is a carbonated deposit resulting from the destruction of tufa buildups situated higher up, and it reaches very sizable thicknesses. In the valley of the Purón, a single generation of tufa deposits from the Holocene has been detected [8], supported in some stretches of the valley by stratified deposits associated with the last episode of intense cold in the recent Pleistocene. These 
deposits have undergone a deep incision, although there are active processes of tufa precipitation in the valley (Figure 3).

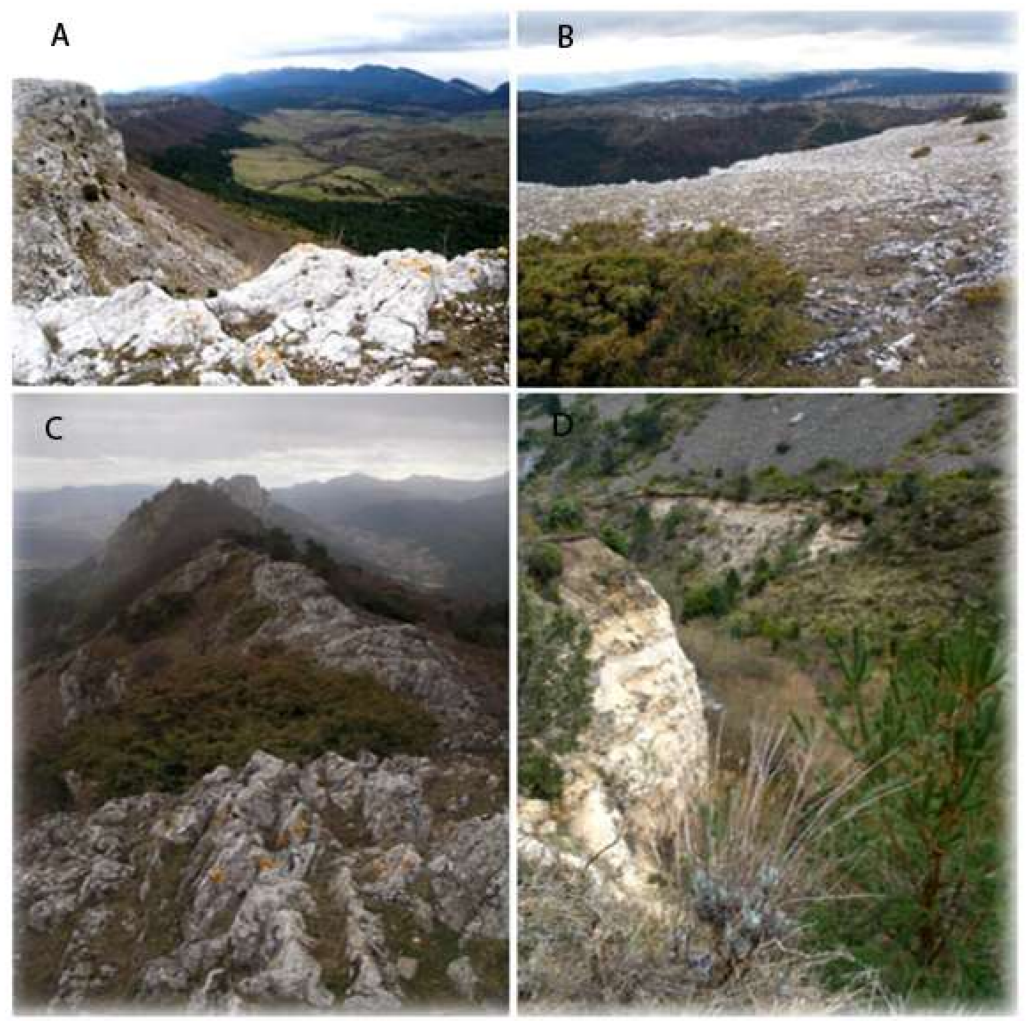

Figure 2. Panoramic views of the Valderejo Natural Park. (A) Panoramic view from Lerón Peak; (B) Panoramic view from El Recuenco; (C) Arrayuelas; (D) Purón River.

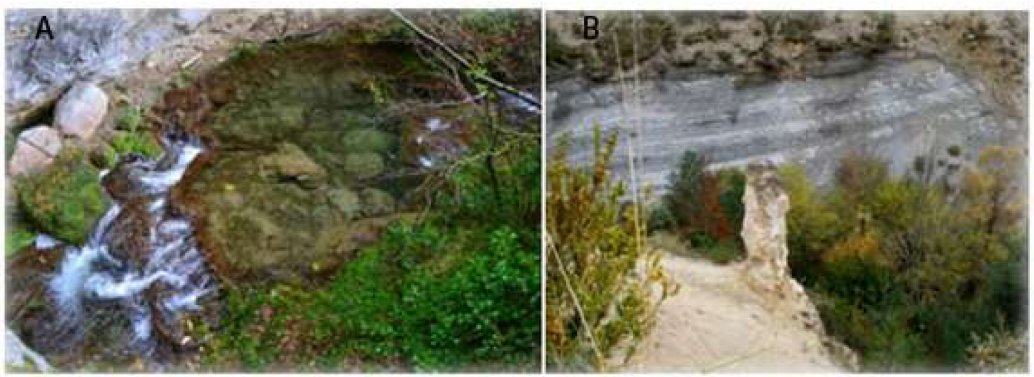

Figure 3. Active and fosil tufa deposits. (A) Tufa cascade barrier; (B) Calcarenitic barrier.

At this moment, Valderejo is a landscape with intense cultural and natural overlap. The marginal location of Valderejo with respect to the large axes of socioeconomic development explains why the park landscape remains in a good condition. Valderejo has a considerable cultural heritage related to the Purón River, a natural step between the Ebro valley and the coast of Cantabria, which has been used since the middle Paleolithic. It has outstanding architectonic, ethnographic, and historical elements, which were the basis of its declaration as an Archeological Park in 2011.

Tourism is an important economic resource to the park and Valderejo is the Natural Park, with the greatest number of visitors in the Basque region. In 2009 this number surpassed 60,000 [9]. It should be mentioned at this point that some of the sites of geomorphological interest in Valderejo have potential for geotourism and must be considered as managed territorial resources in order to guarantee a balance between conservation and sustainability. 


\section{The Geomorphological Map of Valderejo}

Field work and use of the previously mentioned cartographic techniques facilitated the drawing up of this geomorphological map. A genetic and morphological classification has been made of the relief landforms, both of their distribution and the spatial relationship between them. The result is a graphic description of both the inherited structural forms and current forms resulting from processes of erosion, transport, and sedimentation. In this regard, relief is important as one more element of the natural environment, and it presents values with scientific-didactic content that must be taken into account in the management and promote a natural space of geomorphological importance.

Valderejo Natural Park constitutes a structural relief whose morphology derives directly from its geological structure, an anticline whose axis has been eroded and with a predominance of carbonated lithologies (Figure 4). This fact also determines the importance of the presence of the Pleistocene and Holocene tufa deposits.

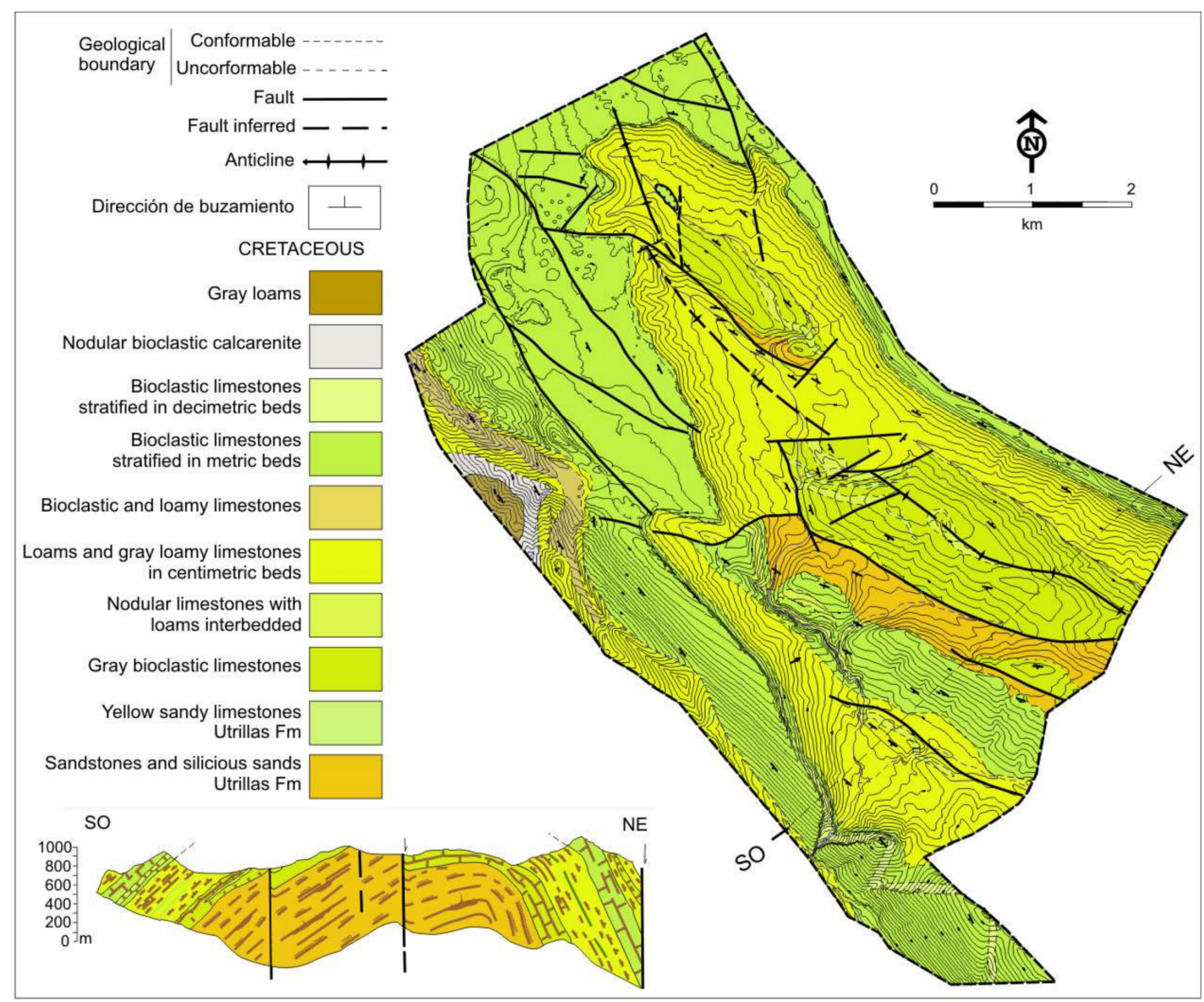

Figure 4. Valderejo Natural Park. Geological sketch.

The map is an important contribution to the geomorphological knowledge of this part of the Alto Ebro, since it differentiates both the structural articulation coinciding with the combe of Arcena and past and present dynamics, among which karsts are outstanding both in their dissolution and precipitation forms. The environmental meaning of the tuff formations, their great fragility and swift response to environmental changes or those induced by humans give the geomorphological map added value as it represents their precise location, dimensions, and present dynamic. The geomorphological map (Figure 5) also has the advantage that it is a necessary diagnostic document of the Habitat $7220^{*}$ of the Habitat Directive of the European Union, which points to these formations as exceptional examples of the overlap between the geological and floristic components. 


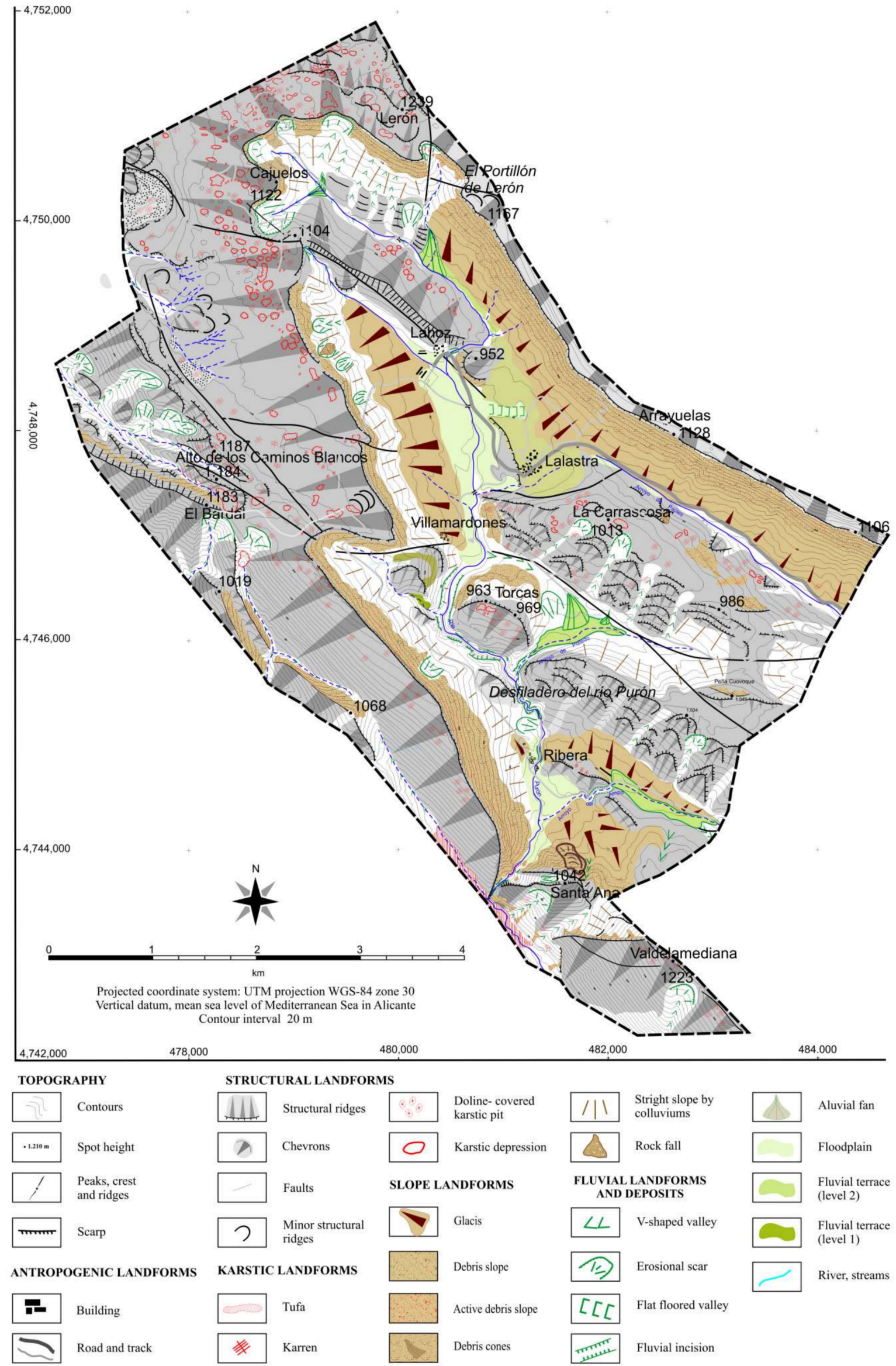

Figure 5. Geomorphological map of Valderejo Natural Park. 


\section{Derived Mapping}

In addition to being a scientifically based document, the geomorphological map is considered an essential tool for territorial management and divulgation of the natural abiotic heritage of the Valderejo Natural Park and its geomorphological articulation. Once adapted, it will be of great divulgatory potential (Figure 6) since it will didactically show the users of the Natural Protected Areas (NPA) the geomorphological and topographic articulation of the landscape, which determine the distribution of the remaining elements of the environment. It serves as a tool for reading and understanding the landscape, more so in natural protected areas in which geomorphology, and structural relief in particular, often play a special role.

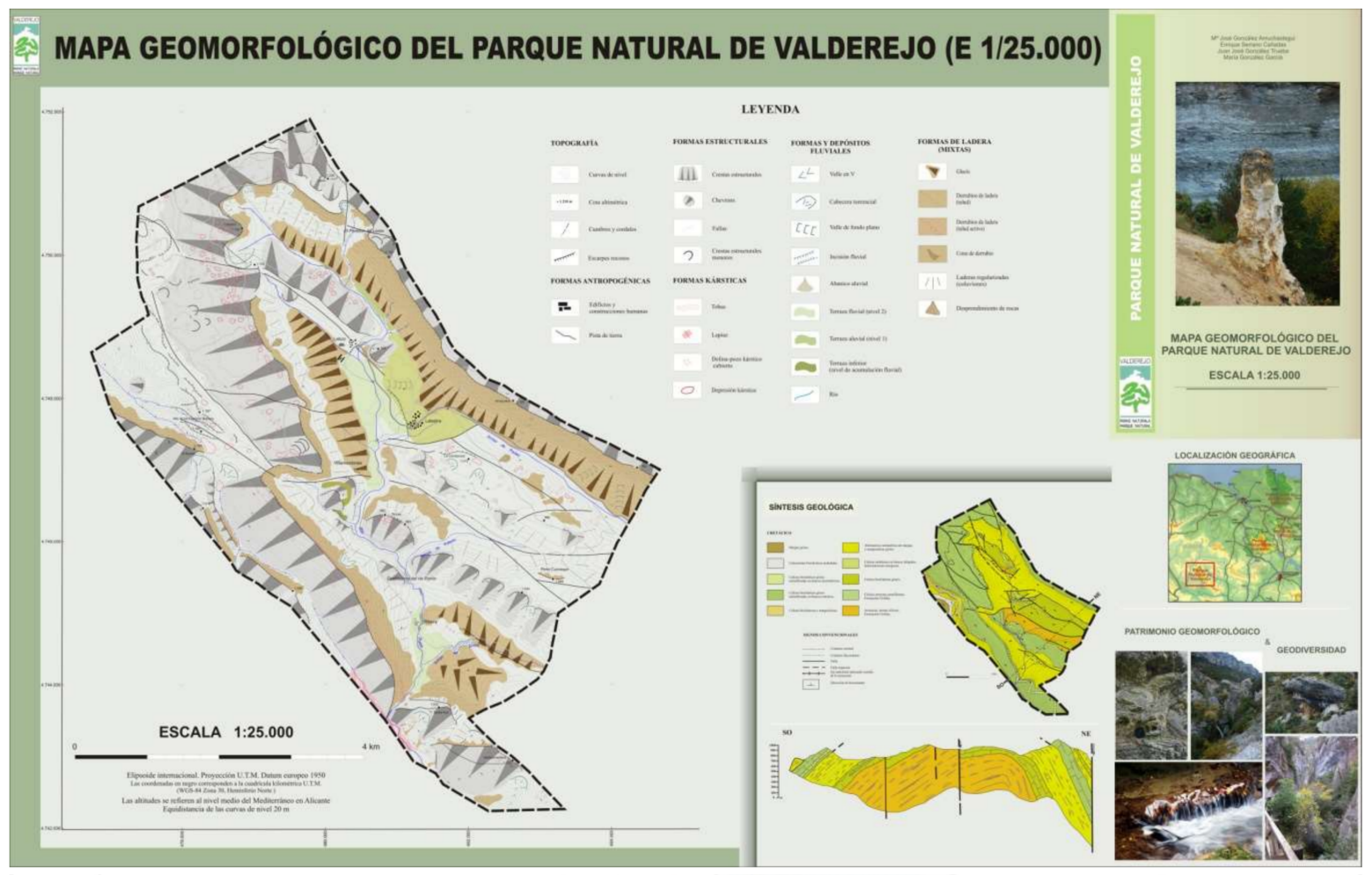

Figure 6. Edition of the geomorphological map to be published by the park managers.

Moreover, morphological mapping is a fundamental tool for territorial management as it constitutes the first step in the elaboration of applied derived cartography:

- Map of geomorphological units (Figure 7), which serve as the basis for other derived cartography: mapping of units of the landscape, of biodiversity.

- Evaluation of geodiversity. Geodiversity mapping is a useful tool for the management and protection of geomorphic, topographic, geologic, pedologic, and hydrologic features. Geodiversity is considered a fundamental part of natural diversity, the support of natural habitats and landscapes and therefore a territorial management tool for nature conservation specifically oriented to territorial decision-making, planning, and education. With these aims we begin with the concept of geodiversity as "the variability of abiotic nature, including lithological, tectonic, geomorphological, soil, hydrological, topographical elements and physical processes on the land surface and in the seas and oceans, together with systems generated by natural, endogenous and exogenous and human processes, which cover the diversity of particles, elements and sites" $[3,9,10]$.

- The inventory and definition of geomorphosites (Figure 8). In this sense it is important to mention that some of the geomorphosites in Valderejo have the potential to become sites of 
touristic interest in themselves and must therefore be considered territorial resources whose management must guarantee the balance between conservation and sustainability [11].

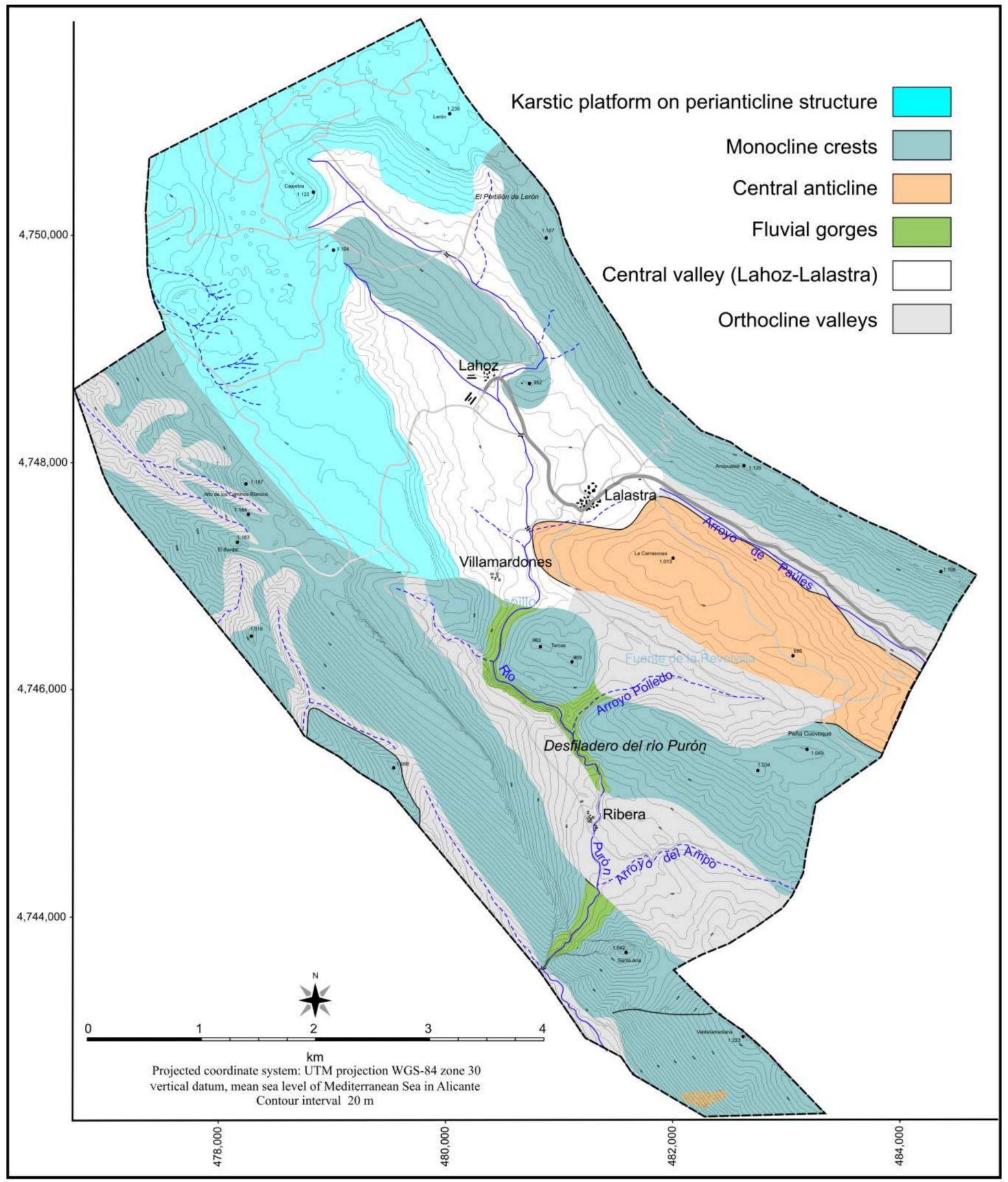

Figure 7. Valderejo Natural Park. Geomorphological units.

- Drawing up of didactic and geotouristic itineraries (Figure 9). At present, the cultural and economic ecosystem of natural heritage services and NPAs are an important resource for consideration by managers and where abiotic and geomorphological elements have special relevance. Natural Protected Areas are territorial resources that receive many visitors with different interests and objectives, although all of them admire and enjoy the landscape. Active 
tourism is one of their main economic activities, and geotourism plays an important role in facilitating the interpretation of its geographical features. In this sense, the geotourism map, as an element of territorial representation, stands out as a necessary tool for guiding and advising both guides and visitors. The result is a document that helps, in a simple way, managers, guides, and visitors to interpret the landscape both before and during the visit to Valderejo.

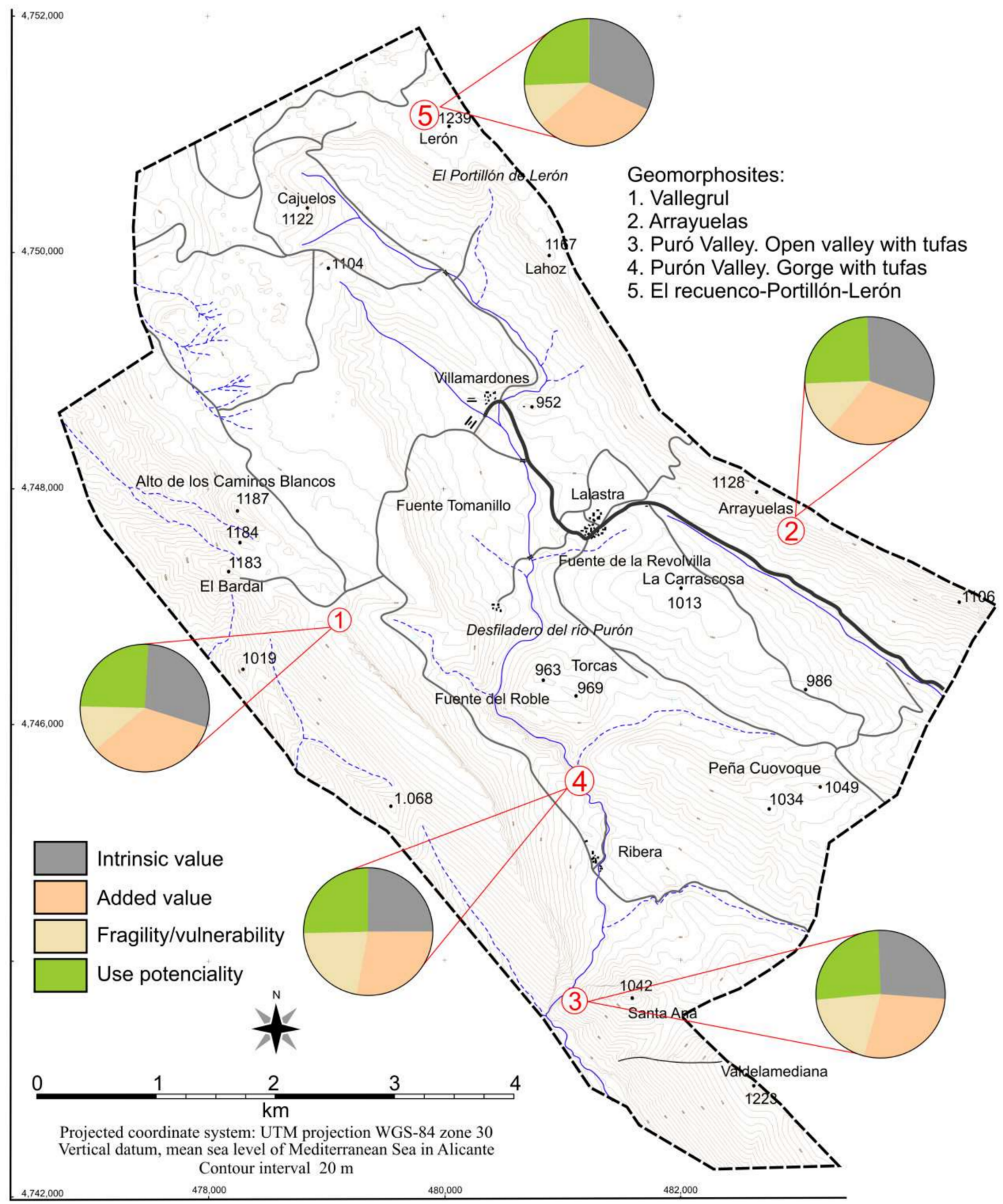

Figure 8. Inventory and valuation of geomorphosites in Valderejo Natural Park geomorpholical units. 

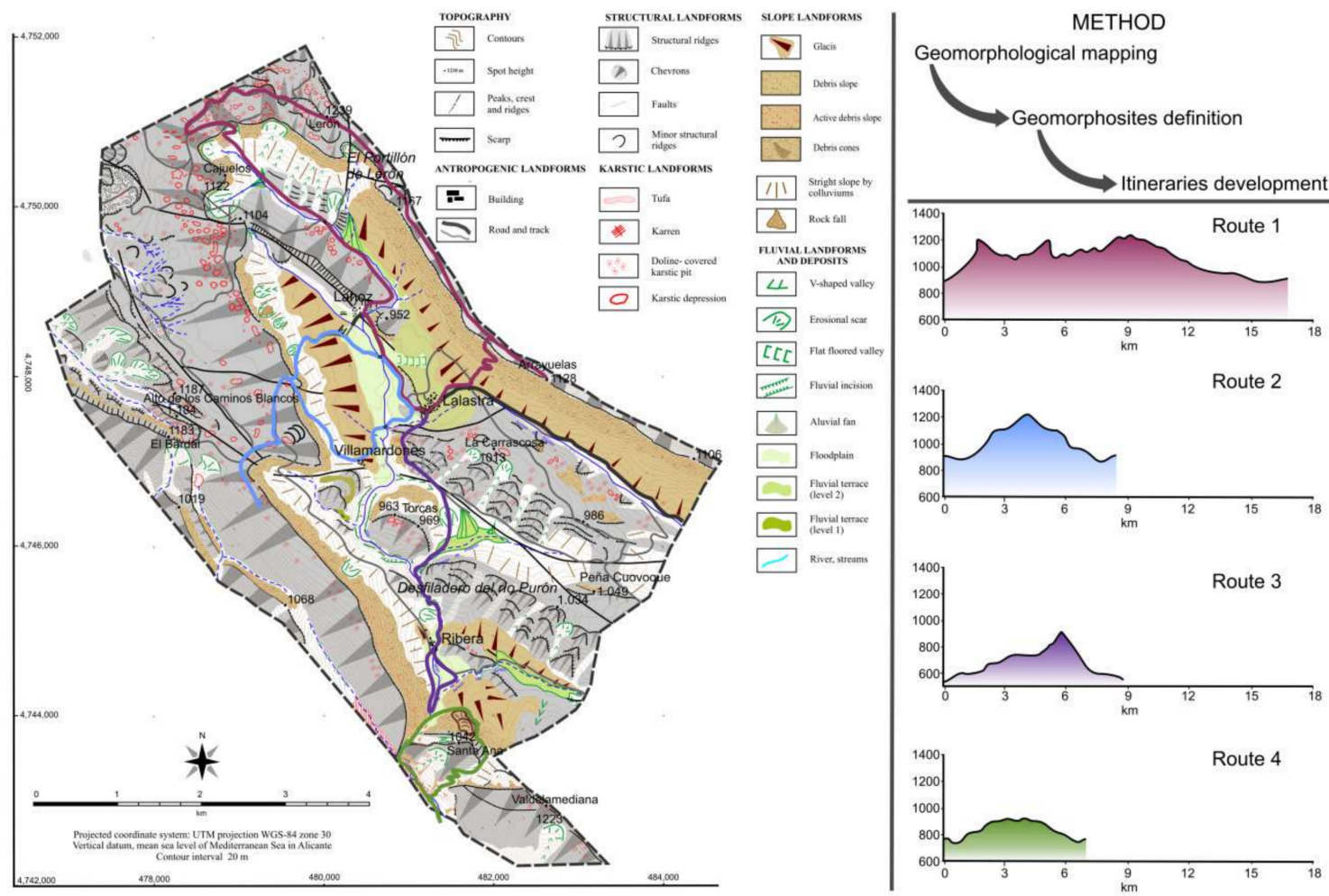

Figure 9. Geotouristic itineraries of Valderejo Natural Park.

\section{Discussion and Conclusions}

Morphological mapping is a scientific document that constitutes an essential tool for understanding the structural articulation of the land and its evolution through the study of its main morphostructures, forms, and associated deposits. Additionally, geomorphological maps are an available and usable management tool for NPA managers as they are fundamental to territorial knowledge by providing a scientifically based document with great promotional potential as simplified geomorphological and geotouristic maps.

Moreover, through geomorphological mapping other maps can be created and applied to the management of NPAs, for example, maps of geomorphological units, landscape units, geodiversity units or the inventory of geomorphosites.

In short, geomorphological cartography is a fundamental tool for establishing a diagnosis of the value of the land resources and geoheritage in protected natural areas, at a time when the importance of geomorphological heritage is becoming clear. In addition, there is a need to develop management proposals linked to the abiotic elements of the landscape.

An exhaustive knowledge of the territory and its geomorphology first requires the drawing up of a geomorphological map. The possibilities for its application turn the map into the first step of territorial analysis. The methodology applied permits specific proposals to be defined regarding the land planning of NPAs, with regard to both the its planning categories and the degree of protection required, from the strictest preservation to the establishment of different conditions imposed for its use.

Author Contributions: This study was carried out by the two authors throughout different field campaigns initiated in the 1990s. Subsequently, the samples obtained in the field were analyzed in the laboratory and the cartography was carried out jointly.

Funding: This research received no external funding.

Acknowledgments: The research is part of the UNESCO09/05 Project (UNESCO Chair in Sustainable Development), the Consolidated Research Group Type A IT622-13 (Department of Geography, Prehistory, and Archaeology, UPV/EHU) and the Project VA029G18 (JCyL-GIR PANGEA). 
Conflicts of Interest: The authors declare no conflicts of interest

\section{References}

1. Reynard, E. Geomorphosites and landscapes. In Geomorphosites; Reynard, E., Coratza, P., Regolini Bissig, G., Eds.; Pfeil: Munich, Germany, 2009; pp. 21-34, ISBN 978-3-89937-094-2.

2. Gray, M. Geodiversity: Valuing and Conserving Abiotic Nature, 1st ed.; Wiley \& Sons: West Sussex, England, 2004; 415p; ISBN 0-470-84895-2.

3. Serrano, E.; Ruiz-Flaño, P. Geodiversity. A theoretical and applied concept. Geogr. Helv. 2007, 3, $140-147$. [CrossRef]

4. Peña Monné, J.L. Cartografía Geomorfológica Básica y Aplicada, 1st ed.; Geoforma Ediciones: Logroño, Spain, 1997; 243p; ISBN 84-87779-31-X. (In Spanish)

5. Vestappen, H.T. Old and new trends in geomorphological and landform mapping. In Geomorphological Mapping: Methods and Applications; Smith, M.J., Aron, P., Griffiths, J.S., Eds.; Elsevier: Oxford, UK, 2011; pp. 13-38.

6. González-Amuchastegui, M.J.; Serrano, E. Cartografía geomorfológica del Valle de Tobalina (Burgos). Cuad. Lab. Xeol. Laxe 1996, 21, 737-748. (In Spanish)

7. Serrano, E.; González-Amuchastegui, M.J.; Ruíz-Flaño, P. Gestión ambiental y geomorfología: Valoración de los Lugares de Interés Geomorfológico del Parque Natural de las Hoces del Alto Ebro y Rudrón. Cuatern. Geomorfol. 2009, 23, 65-82. (In Spanish)

8. González-Amuchastegui, M.J.; Serrano, E. Tufa buildups, landscape evolution and human impact during the Holocene in the Upper Ebro Basin. Quat. Int. 2014, 364, 54-64. [CrossRef]

9. Pellitero, R.; González-Amuchastegui, M.J.; Ruíz Flaño, P.; Serrano, E. Geodiversity and geomorphosites assessment applied to a Natural Protected Area: The Ebro and Rudron Canyons Natural Park (Spain). Geoheritage 2011, 3, 163-174. [CrossRef]

10. Pellitero, R.; González-Amuchastegui, M.J.; Serrano, E.; Manoso, F. Geodiversity map of Valderejo Natural Park (Northern Spain). In Proceedings of the XII Reunión Nacional de Geomorfología, Santander, Spain, 27-31 August 2012; p. 551. (In Spanish)

11. González Amuchastegui, M.J.; Serrano, E.; y González García, M. Lugares de interés geomorfológico, geopatrimonio y gestión de espacios naturales protegidos: el Parque Natural de Valderejo (Álava, España). Rev. Geogr. Norte Gd. 2014, 59, 45-64. (In Spanish) [CrossRef] 